\title{
Anti-immigrant sentiment and majority support for three types of welfare
}

\author{
The case of Germany
}

Tina Goldschmidt

Stockholm University, Department of Sociology

\begin{abstract}
Past research suggests that majority evaluations of welfare deservingness are structured along ethnic dividing lines. The fact that poverty and immigrant status are highly associated across Europe's increasingly ethnically diverse societies may thus lead majorities to withdraw support from welfare programs that transfer money to people who are different from themselves. Utilizing measures of general welfarism, most prior studies have not addressed the interplay between attitudes toward immigrants and support for specific welfare types that rely on different notions of entitlement and attract varying levels of take-up among natives and immigrants. Addressing this gap in the literature and focusing on the example of Germany, this paper asks to what extent anti-immigrant sentiment relates to native-born Germans' attitudes toward the government's responsibility to care for three recipient groups: the unemployed, the old, and the sick. Anti-immigrant attitudes expressed as ethnic prejudice are associated with lowered support for government intervention to assist the unemployed, while support for old-age and sickness assistance does not appear to be related to levels of negative out-group sentiment. The results suggest that those who harbor ethnic prejudice are more likely to oppose aid that is predominantly means-tested, rather than universal or contribution-based, and that does benefit a large number of non-natives. The negative association between prejudice and support for unemployment assistance is independent of concerns with the economic viability of the welfare system in the face of immigration. This points to the relevance of negative affect beyond subjectively rational motives.
\end{abstract}




\section{Introduction}

Since Alesina and Glaesner's seminal publication in 2004, a range of studies have investigated the relationship between immigration-induced heterogeneity and majority support for the welfare state (cf. Stichnoth and Van der Straeten 2013). Attitudes toward immigrants are often regarded as important intermediaries, explaining the largely negative association. Much research has thus also addressed the link between majorities' stance on redistribution and racial prejudice in the USA (Fox 2004; Gilens 2000) and various expressions of anti-immigrant sentiment in Europe (see e.g. Ford 2006; Gorodzeisky 2013; Senik et al. 2009). Most of these studies have utilized measures of generalized welfarism, such as the endorsement of equality and a broader concern with helping the poor. However, this approach may mask important differences in support patterns across specific types of welfare (Schmidt-Catran and Spies [forthcoming]). Especially means-tested as opposed to contributory or universal forms of welfare give rise to pronounced struggles over entitlement and benefit natives and immigrants to different degrees (Crepaz and Damron 2009; Rothstein and Stolle 2003). Moreover, European majorities'support for the various arenas of welfare provision has been shown to be closely linked to their views on the deservingness of primary recipient groups (van Oorschot 2006). Consequently, studying attitudes toward welfare types is important to derive a more differentiated view on which aspects of the welfare state might struggle to retain popular support ${ }^{1}$ in the face of increasing ethnic heterogeneity and anti-immigrant sentiment.

This paper asks to what extent two types of anti-immigrant sentiment relate to native-born Germans' support for government intervention to assist three distinct socially vulnerable groups - the unemployed, the old, and the sick. Germany is an especially interesting context within which to answer this question because it combines the comparatively pronounced presence of anti-immigrant sentiment

\footnotetext{
1 Some prior research even suggests that certain types of welfare may gain support from constituencies that harbor affectively negative attitudes toward immigrants, but simultaneously fear economic displacement due to immigrant competition (cf. Burgoon et al. 2012; Finseraas 2008). While this socalled compensation hypothesis should not be discounted, the present article limits itself to assessing whether concerns about the erosion of majority welfare state support are warranted (also see Section $6)$.
} 
(Decker et al. 2012; Scheepers et al. 2002; Semyonov et al. 2006) with markedly different patterns of welfare use among native and non-native residents across meanstested and contributory as well as universal welfare programs (Engels et al. 2011).

Using data from the 2006 German General Social Survey (ALLBUS) and the International Social Survey Programme (ISSP) I find that anti-immigrant sentiment, expressed as affective prejudice, is indeed associated with lowered support for government intervention to assist the unemployed. At the same time, support for oldage and sickness assistance does not appear to be related to levels of ethnic prejudice. This then implies that those who harbor prejudice oppose means-tested aid that does benefit a notably large number of non-natives, but embrace contributory and universal programs that predominantly benefit native recipients. Interestingly, neither of these associations is dependent on the belief that non-natives impose an (economic) burden upon the social system. This points to the relevance of negative affect beyond subjectively rational motives.

\section{Anti-immigrant sentiment and support for the welfare state}

Past research has identified two main pathways through which attitudes toward immigrants may lead to a decline in native majorities' support for social welfare.

The first pathway assumes that in-group biases render natives inclined to feel less solidarity and more social distance toward non-Western immigrants in particular, raising opposition to their inclusion in the welfare system. Commonly defined as the preferential treatment of those who are similar to oneself on one or more salient dimensions, such as race, religion, or language, a long line of research in social psychology has confirmed the importance of in-group bias for how individuals choose to allocate resources (Brewer 1979; Tajfel 1970). Criteria along which in- and out-groups are defined depend heavily on the object of competition between the groups at hand (Tajfel 1970). In-group biases and negative out-group sentiment based on ethnic dividing lines may thus rise to particular salience in shaping natives' attitudes toward welfare programs that are perceived to overly benefit immigrants. That is, if poverty, welfare dependency, and immigrant status become associated, the majority can be aroused to embrace welfare chauvinistic ideals of 'welfare for $u s$ but not them' (Alesina and Glaesner 2004: 134). 
In line with the in-group/out-group argument, comparative studies have revealed that most European societies share a common deservingness culture, according to which majorities consider the (native) elderly to be most entitled to government assistance, followed by the sick, and placing immigrants at the very bottom of the entitlement scale (cf. van Oorschot 2006). Studies addressing this welfare chauvinism have often investigated majorities' inclination to exclude less qualified, non-Western labor immigrants and asylum seekers in particular from accessing social rights - a tendency which appears to be widespread among European and American majorities (Hainmueller and Hiscox 2010; Helbling and Krisi 2014), albeit with great variation across societies. For instance, Scheepers et al. (2002) find that native-born Germans, Austrians, Danes, and Belgians are notably more likely to favor excluding foreign residents from social rights than natives in 11 other European countries (also see Gorodzeisky and Semyonov 2009). Taking the case of Israel, Gorodzeisky (2013) shows that majority respondents' willingness to exclude nonJewish workers from accessing basic social rights is conditionally dependent on their prejudicial views toward the immigrant population.

Rather than studying welfare chauvinism as natives' desire to merely exclude immigrants, few studies have considered the consequences of negative out-group sentiment for European majority support for the welfare state in general. Ford (2006) shows that Britons who admit to being prejudiced against people of other races are significantly less favorable toward redistribution at large. Albeit looking at less clearly affective expressions of anti-immigrant sentiment, Finseraas (2008) also finds that native-born citizens across European societies are less likely to support redistribution, if they believe that immigrants do not integrate well culturally and should be kept from accessing social rights.

A second channel of influence discussed in the literature suggests that it might rather be natives' cognitive response to the reality of immigration-induced heterogeneity that lowers their support for the welfare state. Specifically, majority citizens' concern with immigrants' use of welfare and costs to the social system appear to be of importance, as they represent 'the material dimension of [the intergroup] conflict' (Crepaz and Damron 2009: 439). Fong et al. (2006) show that people revise their willingness to help the poor if they perceive them as cheating the system or failing to contribute. People who feel that immigrants take undue advantage of and 
hence place a burden upon the welfare state can thus be expected to be less supportive of means-tested programs in particular, as those are not based on prior contributions (also see Section 3).

Stating that negative attitudes toward immigrants can be based on cognition rather than affect does of course not imply that they necessarily represent objectively true facts. In the absence of relevant personal experience, stereotyping attitudes, such as the belief that immigrants generally impose a burden upon the welfare state, are informed by trusted sources, such as friends and media reports (Rydgren 2004). Indeed, looking at 15 European countries, Schmidt and Spies (2014) find that the notion of immigrants' benefitting more from welfare than they contribute only limits majority support for redistribution if political parties emphasize such claims. Because individuals use these same third-party informed, generalizing, and efficient modes of reasoning as they navigate most aspects of their daily lives, ethnic stereotypes may appear subjectively rational, given the cognitive confines of the individual (Hamilton and Trolier 1986). However, as Rydgren (2008) demonstrates in his study of radical right-wing voters in six European countries, individuals' affective and cognitive responses to the presence of immigrants do not always overlap, and those believing that immigrants generally place an unjustifiably high burden upon the welfare budget do not necessarily also hold affectively negative attitudes against them. The two types of anti-immigrant sentiment should hence be treated as distinct concepts, especially when studying their relevance for majorities' support for the welfare state.

While subjectively rational stereotypes may matter beyond and independent of prejudice (suggesting a net effect), research in social psychology also suggests that individuals tend to use their prejudices as heuristics in assessing situations (Pratkanis 2014 [1989]). When asked to judge the behavior of a white taxi driver who refused to accept a black client, participants in an experiment conducted by Khan and Lambert (2001) were more likely to regard the driver's behavior as rational rather than discriminatory if they harbored negative prejudice against blacks. Their knowledge that blacks are more often involved in crime than other racial groups led them to stereotype the black customer as a potential criminal, rendering the driver's refusal appropriate, and indicating a mediation of prejudice via subjective rationality. However, thinking of welfare again, it may equally be the case that natives who are negatively prejudiced must also belief that immigrants abuse the social aid system to 
make their prejudice matter for their views on welfare (cf. Peffley et al. 1997; Schmidt and Spies 2014). This then suggests an interaction (moderation) among the two types of anti-immigrant sentiment. A number of studies have investigated this interplay of anti-immigrant attitudes:

Larsen (2011) studies two measures of majority attitudes toward blacks in the USA, and non-Western immigrants in the UK, Sweden, and Denmark. The first measure is affective, asking whether respondents would mind living in a neighborhood where half of the population belonged to the relevant out-group. The second one reflects a (subjectively rational) stereotype, pertaining to the out-group's work ethic. Negative attitudes along both affective and subjectively rational dimensions appear to significantly lower support for government spending on assistance for immigrants in particular as well as redistribution in general. The relationships seem to be as strong in the three European countries as in the USA. Gorodzeisky (2013) also shows that subjectively rational notions of cultural and economic threat are not directly, independently associated with attitudes toward the allocation of social rights to non-natives in Israel, but that they do tend to bolster prejudice. Senik et al. (2009) use a research design similar to Larsen's but expand the comparison to 22 European countries. They find that, among majority citizens, an affective desire for social distance (as expressed by an opposition to inter-ethnic marriage) is more strongly associated with favoring equal opportunities than the notion that immigrants rely on the welfare state too much. Importantly, Senik et al. find no significant interaction among the two main predictors. Other than Gorodzeisky (2013) and to some extent Larsen (2011), they hence conclude that the relationship between negative affect and attitudes toward the welfare state is not moderated by subjectively rational concerns about the economic implications of immigration.

\section{Notions of welfare entitlement and take-up patterns in Germany - why program types matter}

What studies investigating the two presented pathways have in common is their reliance on dependent variables that capture respondents' endorsement of general, welfare-related values, for instance, pertaining to equality of opportunity or outcomes. However, there are at least two reasons why natives' attitudes toward non- 
Western immigrants in particular should not affect their support for all types of welfare equally, rendering the persistent focus on measures of generalized welfarism problematic.

First, past research has shown that different types of welfare rely on different notions of social justice and entitlement, not all of which are likely challenged by natives' attitudes toward immigrants. The distinction between means-tested and universal or contributory programs is of particular importance in this regard.

Universal welfare programs financed by taxpayer contributions make it 'difficult to stigmatize receivers of government support', since 'almost everybody contributes and receives' (Crepaz and Damron 2009: 449). Similarly, welfare benefits that are directly tied to prior contribution are connected to a strong sense of entitlement and unlikely to raise questions about recipients' deservingness. Because they do not imply a clear-cut distinction between providers and receivers, these types of welfare are unlikely to activate out-group biases or garner opposition based on concerns about immigrants' burdening the system while failing to contribute. Provisions within Germany's conservative welfare regime - the case studied here are primarily organized as social insurance programs financed by employer and employee contributions (cf. Esping-Andersen 1990). This is true for the country's old-age pensions and 12-month unemployment insurance ( $A L G I)$, both of whose benefit levels are directly tied to the amount of prior contributions made, as well as for the public health insurance, which is more universal in character.

Since 2005, comprehensive reforms ${ }^{2}$ have transformed a large part of the German unemployment insurance into a new type of aid for the long-term unemployed (known as ALG II or Hartz IV). The program comprises means-tested transfer payments redeemable by legal working-age residents (including non-citizens) without an alternative source of income. Means-tested schemes have been shown to be inherently divisive, as they necessitate a formal distinction between those in need and those able to provide for themselves (Rothstein and Stolle 2003). The program

2 Despite widespread public opposition proclaiming 'the end of the welfare state', Germany's Left Party and labor unions were the only political forces taking an opposing stance to the system changes. Beyond political ideology, union membership thus likely constitutes an important predictor of German welfare preferences, especially around the time of the reforms, and is taken into account in the analyses presented here. 
structure tends to create a sharp dividing line between a self-sufficient, working ingroup that finances the livelihood of and an inactive out-group that enjoys 'the "hammock" of the welfare state' (Crepaz and Damron 2009: 446). Indeed, Finseraas (2008) suggests that non-exclusive, means-tested welfare types might be the key to explaining the link between anti-immigrant sentiment and welfare state opposition. This conclusion is based on the observation that negative attitudes toward immigrants are associated with the strongest welfare opposition in Europe's social-democratic welfare states, whose predominantly tax-financed programs make it hard to prevent any legal resident from benefiting (ibid.). Yet, similar patterns are likely detectable within single European welfare states, across means-tested versus contributory or universal welfare programs, as well (Finseraas 2008).

Based on their finding that even within the German conservative welfare state the regional share of immigrants is significantly negatively associated with generalized majority support for redistribution over time, Schmidt-Catran and Spies (forthcoming) conclude that the relationship is "not mediated by the national welfare regime at all' but that inter-program differences are likely at the heart of the observed relationship. Whether the negative association may in fact be driven by Germans' opposition to means-tested aid for the unemployed rather than the welfare state at large remains an open question, which is addressed in the analyses presented here.

Second and directly related, welfare programs differ in terms of how much natives and non-natives actually benefit (cf. Figure 1). As discussed earlier, it seems likely that negative sentiment against non-native out-groups is relevant only to majority support for those welfare programs that are actually perceived to be used by immigrants. Rendering support for this line of reasoning, Gilens (2000) shows that white Americans are highly supportive of welfare programs that require previous contribution and benefit favored groups (e.g. the elderly). Only when it is understood as the kind of need-based aid from which black citizens benefit more than any other ethnic group, does welfare meet opposition among prejudiced whites, who consider blacks to be lazy and unmotivated to help themselves. Gilens thus concludes that American welfare attitudes are ethnicized, that is, that deservingness is tied to ethnicity or, rather, to being a member of the white majority. 
[Figure 1 about here]

Figure 1 shows primary sources of income for native-born Germans and residents with a migration background ${ }^{3}$ in 2006/2007, when the survey used in this paper was conducted. It should be noted that even though the West German Federal Republic actively encouraged the in-migration of Southern European, Turkish, and Yugoslavian guest workers from the 1950s to the early 1970s, Germany did not experience large-scale immigration until the 1990s. Fuelled by the dissolution of the Soviet Union and the Yugoslav Wars, the share of foreign residents increased from $1.2 \%$ in 1961 to $8.8 \%$ in 1995 (Kohls 2011). Today, 13\% of all German residents were born abroad (OECD 2014) and 20.5\% have a so-called 'migration background', rendering Germany's non-native population share one of the largest in Europe (DEStatis 2014). Since 2005, Germany has invested about 25\% of its annual GDP in social expenditures, making it one of the largest welfare spenders in Europe (Adema et al. 2012). The social budget is chiefly distributed across the three founding pillars of the German welfare state: old-age pensions, public health and disability insurance, and assistance for the unemployed. In 2013, the retirement and health insurance systems attracted 31 and $29.5 \%$ of all government social spending, while payments to the unemployed amounted to only 12\% (BMAS 2014).

In $2006 / 2007,25 \%$ of all Germans and only $10.5 \%$ of individuals with a migration background received their main income from retirement payments (Figure 1). Similarly, natives received disability and long-term sickness benefits twice as often as residents with a migration background, though the overall share of both recipient groups is expectably low, with 0.15 and $0.07 \%$ respectively (not shown; DEStatis 2009). Even though studies have shown that especially non-Western immigrants tend to face significantly higher morbidity risks than the German majority, this group is also much less likely to use the public healthcare system for both preventive and acute care services (Kohls 2011). Taken together, these takeup patterns reveal that the old-age pension and health pillars of the German welfare

3 The German Federal Statistical Office defines individuals with a migration background as those who were born abroad, born in Germany as foreign nationals, or born in Germany as German citizens with at least one foreign-born parent. The category 'foreign nationals born in Germany' arises from the fact that German citizenship is granted primarily on the basis of parental citizenship (jus sanguinis). 
system do not only attract the largest shares of government social spending, but also include the kinds of transfers that mainly benefit natives.

Like in many other countries, immigrant status and socioeconomic disadvantage are associated in Germany as well. While less than half of all nativeborn Germans (43\%) drew their principal income from employment, the share of gainfully working residents with a migration background was even lower, at $36 \%$. Consequently, non-natives were twice as likely to received long-term unemployed aid (ALG II) and other means-tested assistance compared to natives (cf. Engels et al. 2011). However, it should be pointed out that the share of non-natives relying on their own families rather than the government to cover the majority of their financial needs exceeds that of the native population by a factor of almost two as well. This reveals an important source of economic self-sufficiency, which is largely overlooked in Germany's often negatively charged political and media debates about immigrants' welfare use. Past research has revealed a tendency of German media reports to present unemployment as self-inflicted and the unemployed as lazy abusers of transfer payments (cf. Uske 2000). This general stigma becomes even more pronounced when unemployment, dependence on largely means-tested aid, and immigrant status overlap.

Surveys performed by major polling agencies point to consistently high levels of agreement with the statement that Muslim residents in particular place a burden on the German social system because of their alleged unwillingness to work and adapt culturally (Hierl 2012). Yet, disconfirming common preconceptions regarding immigrants' preference for welfare over employment, Castronova et al. (2001) use German panel data to conclusively demonstrate that immigrants are not more likely to claim means-tested benefits than native-born Germans with similar socioeconomic profiles. They are just more likely to be and remain unemployed.

Overall, German majority attitudes toward immigration and non-native residents used to be amongst the most negative in Europe throughout the late 1990s and early 2000s (Scheepers et al. 2002; Semyonov et al. 2006), and recent reports confirm that xenophobic sentiments continue to spread, especially in East Germany (Decker et al. 2012). The heightened presence of such attitudes coupled with pronouncedly different patterns of welfare use among native and non-native residents make Germany an interesting setting within which to study the nexus between anti- 
immigrant sentiment and program-specific support for the welfare state. Based

on the discussion of insights from prior research and the characteristics of the German case, the following hypotheses are derived for empirical testing:

Because the division between users and non-users is clearly identifiable and marked by unequal take-up among natives and non-natives in Germany, ethnic ingroup preferences are likely to matter for support for means-tested aid in particular (pathway 1 - in-group bias). Specifically, I hypothesize that

Hypothesis 1: The stronger the ethnic prejudice in members of the Germanborn majority public, the lower is their support for means-tested government intervention to assist the (long-term) unemployed.

However, even when it comes to support for means tested aid, ethnic prejudice and in-group preferences might only come to matter if immigrants are actually perceived as placing a financial burden upon the welfare state, for example, by relying on these programs too much (pathway 2 - subjective rationality as a moderator). I hence also test the hypothesis that

Hypothesis 2: The relationship between ethnic prejudice and support for means-tested government intervention to assist the (long-term) unemployed is moderated by, i.e. dependent upon, the extent to which people also make the subjectively rational assumption that immigrants are a burden to the social system.

Finally, because universal as well as contributory programs do not lend themselves to dividing providers from recipients and are hence less likely perceived as benefiting any one (ethnic) group more than another, theory on in-group bias (pathway 1) also suggests that

Hypothesis 3: Compared to support for means-tested unemployment aid, attitudes towards universal aid for the sick and contributory pensions for the old will be much less strongly, if at all detectably, related to ethnic prejudice.

The theoretical causal pathway linking the two types of anti-immigrant sentiment discussed here to attitudes toward welfare is much clearer for ethnic prejudice, compared to subjectively rational concerns regarding immigrations' economic implications. On the one hand, the relationship between prejudice and 
support for means-tested welfare in particular is neither intuitive nor obviously endogenous: based on the extensive sociological and social psychological literature on the importance of in-group biases in shaping majorities' redistributive choices, it seems reasonable that negative affect toward non-native out-groups should precede the disliking of welfare programs that do indeed, or are perceived to overly benefit these groups. At the same time, it is not evident that natives who harbor affectively negative prejudice toward immigrants should invariably oppose means-tested aid in particular. For instance, ethnic prejudice is more widespread among those with limited economic resources and education, who are themselves likely to benefit from generous transfer payments and for whom support for government aid and negative out-group affect thus appear to coexist (cf. Crepaz 2008).

On the other hand, the subjectively rational assumption that immigrants threaten the economic viability of the welfare state (pathway 2) gives rise to two plausible causal stories. If natives first perceive the over-representation of immigrants among the recipients of non-contributory, means-tested welfare programs and thereafter come to be concerned about whether the government can and should afford to provide such assistance, we might expect that

Hypothesis 4: The stronger the sense of immigrants' burdening the social system, the lower the support for means-tested government intervention to assist the (long-term) unemployed.

Hypothesis 5: Compared to support for means-tested unemployment aid, attitudes towards universal aid for the sick and contributory pensions for the old will be much less strongly, if at all detectably, related to the perception of immigrants as a burden to the social system.

However, it might also be the case that natives who are especially fond of the welfare state are more likely to be concerned with immigration as one potential threat to the continued viability of generous social systems. If that was the case, the theoretical causal pathway between the degree to which immigrants are regarded as a burden and support for either one of the three welfare programs might either be reversed or, in fact, endogenous. Given that panel data capturing both support for different types of welfare and attitudes toward immigrants is not yet available, I am unable to establish whether welfare attitudes precede attitudes toward immigrants as a 
burden to social systems or vice versa. In the context of my cross-sectional analyses, the models testing Hypotheses 1-3 are thus preferable from a theoretical point of view, while the tests of Hypotheses 4 and 5 should be considered as preliminary sensitivity checks only.

\section{Data and Method}

Data sets adequate to studying the relationship between both affective and subjectively rational expressions of anti-immigrant sentiment and specific types of welfare are rare. The 2006 version of the ALLBUS constitutes a valuable exception in this regard. It contains not only an extensive module on majority attitudes toward resident foreigners but also a battery of ISSP items that measure respondents' stance on the role of the state in providing social aid for a variety of recipient groups instead of merely gauging support for the welfare state in general.

In 2006, 3,421 face-to-face interviews were conducted with German citizens and residents with a migration background. Since this study aims at investigating support for welfare assistance in relation to the German majority's attitudes toward non-natives, excluded from the analyses were foreign citizens, respondents with at least one parent belonging to one of the three immigrant groups to which the ethnic prejudice predictor refers ${ }^{4}$, as well as people who gained citizenship only after birth. Current citizenship was not used as a selection criterion, because so-called Aussiedler, a relatively large immigrant group of ethnic Germans from Eastern Europe, are entitled to naturalize and reside in Germany without formal restrictions. By defining the sample as 'all citizens' this important minority group would be included as well. Since only about half of the ALLBUS respondents participated in the ISSP module on welfare, the sample was further restricted to 972 cases.

It should also be noted that the period of data collection precedes the global economic crisis. In 2006, German economic growth and employment rates reached a six-year high (Räth and Braakman 2007) and news reports focused on the football

\footnotetext{
4 This refers to individuals with at least one parent hailing from Turkey, the USSR or Eastern Europe (potential Aussiedler), and the former Yugoslavia (potential asylum seekers). The remaining group of respondents with one or both parents born in Western Europe or North America were retained in the sample, as excluding them did not alter the analytical findings.
} 
world championship rather than questions of immigration and integration. The estimates of the relationship between attitudes toward non-natives and welfare program support presented here are thus likely conservative and less pronounced than the patterns that may emerge from a future replication of the utilized modules.

\subsection{Welfare attitudes in Germany}

The dependent variables included in the regression models presented here capture attitudes toward state intervention to provide a decent standard of living or adequate care for the unemployed, the old, and the sick respectively. ${ }^{5}$ Conceptually, these single-item measures come closest to demonstrating the perceived deservingness of different welfare recipient groups. While attitudes toward government spending on a specific area of social policy are likely tied to considerations of economic costs and benefits, stating that the government should be responsible for the wellbeing of certain disadvantaged groups seems much more closely tied to preconceived notions of how legitimately in need these recipient groups are.

The set-up of the dependent variables allowed respondents to choose among one of four levels of support for each type of government social intervention, ranging from complete opposition (1) to full endorsement (4). While the response categories are ordered, we should not expect that they are also equally distant from one another, rendering the standard linear regression approach inappropriate. Instead, the data are analyzed using ordered logistic regression, which assumes that the observed outcome, $\mathrm{Y}$, is a function of a latent, continuous variable, $\mathrm{Y}^{*}$ (here 'degree of support for government intervention'). As $\mathrm{Y}^{*}$ takes on an infinite range of values that are divided by various threshold points, respondents' scores on the latent variable determine into which of the observed outcome categories they fall.

Also referred to as the proportional odds model, ordered logistic regression further assumes that the relationship between the explanatory variable is the same across all levels of the outcome variable. Log-likelihood and Brant tests were

5 Original question: 'Please indicate to what extent you believe that it should be the government's responsibility to provide

a) a decent standard of living for the unemployed

b) a decent standard of living for the elderly

c) health care to the sick'

$1=$ never responsible; $\ldots 4$ = always responsible (answer coding reversed in original survey) 
conducted and confirmed that the proportionality assumption was met. In addition, standard errors were conditioned on the distribution of cases across 156 sample points, consisting of 52 addresses each, to account for the potential effects of data clustering. ${ }^{6}$

[Figure 2 about here]

Figure 2 shows response distributions across the four answer categories for each of the three dependent variables for East and West German respondents separately. Even though the welfare state receives comparatively high levels of support among the German general public, studies have shown that East Germans are consistently more supportive of all types of welfare programs (Lippl 2001; Mau 2001). This is also reflected in the ALLBUS data, especially when it comes to assistance for the unemployed:

There is a near consensus among all native respondents regarding the government's responsibility to provide health care for the sick and a decent standard of living for the old. By contrast, as many as 8 and $27 \%$ of all West Germans thought that the government should never or not be required to provide a decent standard of living for the unemployed. Though to a lesser degree, East Germans are also much less likely to regard the state as the legitimate provider of assistance for the unemployed, with $3 \%$ choosing the 'never' and 17\% selecting the 'not responsible' categories. Similarly, though not shown here, only $30 \%$ of all German respondents would support an increase in government spending on aid for the jobless, while $51 \%$ favor higher spending on old-age pensions and $62 \%$ believe that the state should invest more to subsidize health care (ALLBUS/ISSP 2006; own calculations).

German welfare preferences are thus clearly differentiated by program and recipient types, with support for unemployment aid - Germany's primary meanstested form of welfare - being much lower than attitudes toward any other large area

\footnotetext{
6 As multiple regression analysis requires the independence of observations, untreated data clustering may lead to an underestimation of standard errors and spuriously significant effects (Hox 1995). A comparison of unconditioned and conditioned standard errors derived from the ordered logistic regression analyses reveals no notable difference in standard error sizes. However, data limitations (too few cases per sampling point) made the estimation of more sophisticated fixed-effect ordered logit models impossible.
} 
of social government intervention. Scholars remain at odds about whether to attribute the apparent attitudinal divide between East and West Germans to socialization or self-interest. Some argue that East Germans' attitudes toward redistribution are strongly shaped by their socialization in the German Democratic Republic (GDR) or among family members who were raised in the socialist system (Andreß and Heien 2001). Others point to the fact that since the country's reunification in 1989, unemployment has remained much higher in the East and many East Germans are aware that 'a socially acceptable transformation [of two states into one] would not have been possible without the welfare state's engagement' (Mau 2001: 24-25).

\subsection{Ethnic prejudice and subjective rationality}

A similar socialization vs. self-interest debate exists over how to explain the consistently higher levels of anti-immigrant sentiment among East as opposed to West Germans (Gerhards and Lengfeld 2013; Raijman et al. 2003). While some blame the virtual absence of integration efforts in the GDR (Bade and Oltmer 2004), others attribute higher levels of negative out-group sentiment to the insecurities and status losses incurred by many East Germans since the reunification (Friedrich 2001). Whichever explanation is more valid, socialization in East Germany is one of the most crucial controls included in this study, as it has the capacity to influence the three outcome variables and the predictors of main interest. ${ }^{7}$

Affective prejudice toward non-natives is measured on an additive scale of three items that ask respondents to rate the extent to which they would mind if a Turk, an Aussiedler, or an asylum seeker married into their family. The overall scale ranges from 1 to 7, where higher values signify a greater desire for social distance. A Cronbach's alpha of 0.88 was obtained for the ethnic prejudice scale, indicating excellent reliability.

\footnotetext{
7 Separate analyses for East and West Germany are not possible, due to the limited number of cases. Furthermore, an additional geographic control (interacted with the two measures of anti-immigrant sentiment), capturing the percentage of foreign residents as a share of the total population in respondents' districts of residence (Kreis), did neither achieve statistical significance, nor notably affect the overall model fit, the observed associations' significance or their magnitude. Albeit repeatedly linked to levels of nativist resentment (McLaren 2003; Quillian 1995; Wagner et al. 2003), the relationship between ethnic prejudice and welfare preferences does not appear to be sensitive to contextual diversity. The diversity indicators were thus not included in the final regression models and are not presented here.
} 
At 16.4 and $14.2 \%$ of the total population with a migration background, Turks and expatriates from Eastern Europe are Germany's largest non-native groups (Rühl 2009). Moreover, in 2006, Germany received 30,100 asylum seekers. This number has been increasing rapidly since then, making Germany the second largest recipient country of refugees in the EU in 2011 (Eurostat 2012). In the early 2000s, German attitudes toward these three non-native groups were the most negative, both compared to other non-native groups within Germany, such as Italian or Vietnamese communities (Appelbaum 2002) and, in the case of Turks, compared to how other European majorities feel about their largest domestic minorities (Pettigrew 1998).

The ALLBUS 2006 also asked respondents to rate their agreement with the statement that 'foreigners who live in Germany are a burden to the social welfare system' $(1=$ completely disagree, $7=$ completely agree $) .{ }^{8}$ I use this item to capture the subjective rationality of anti-immigrant sentiment, that is, the notion that there is an undue economic cost attached to the presence of foreigners. Since the survey was conducted in German, it should be noted that the German word for 'foreigner' (Ausländer) can refer to both first- and second- generation immigrants, making it likely that respondents considered both as a joint non-native out-group. If it is true that ethnic prejudice only lowers majorities' support for particular welfare programs because benefits are perceived to disproportionately benefit non-native claimants, the effect should be conditional on holding the belief that non-natives do impose a burden upon the social system (Hypothesis 2, Appendix 4 and Models 1-3C).

Albeit statistically significant, the correlation between the two measures of anti-immigrant sentiment is very moderate in magnitude $(r=0.34)$, supporting the assumption that both represent distinct concepts. Yet, as explained in section 2, associations between the subjectively rational form of anti-immigrant sentiment and support for the three types of government intervention (Hypotheses 4 and 5, Models 1-3B) should be considered with care, as questions of endogeneity and causal

8 The survey contains six questions pertaining to the impact of foreign residents on the German economy and welfare state (e.g. whether they 'take away/create jobs' or 'help to finance the pension system'). However, because these items are only weakly correlated $(0.2<\mathrm{r}>0.5)$ and hence not satisfactorily scalable, I rely on the single-item measure instead. In substantive terms, asking whether immigrants are perceived to be 'a burden to the social system' also gets most directly at the notion of welfare chauvinism, rather than e.g. economic threat (cf. Finseraas 2008; Schmidt and Spies 2014), that is of primary interest in the present analysis. 
ordering that cannot be addressed in the cross-sectional set-up of this study. At least from a theoretical perspective, the causal pathway between prejudice to welfare preferences (Hypotheses 1 and 3, Models 1-3A) seems much clearer, though all results presented below should of course be regarded as associations, rather than effects.

In line with prior research on the determinants of welfare attitudes, measures of individual stakeholder status, such as income and labor market position, are taken into account, as are factors of socialization, such as age, gender, and education, as well as political alignment. Appendices 1 and 2 provide descriptions and summary statistics for all independent variables considered in the analyses.

\section{Results}

Tables 1-3 present nine ordered logistic regression models that were specified to explore how affective and subjectively rational expressions of anti-immigrant sentiment relate to native-born Germans' support for government intervention to assist the unemployed, the elderly, and the sick.

[Table 1 about here]

Confirming Hypothesis 1, the bivariate relationship between ethnic prejudice and support for government assistance for the unemployed is negative and significant at the five-percent level (Appendix 3). The association gains in strength and significance as controls for economic self-interest, socialization, and political ideology are added to the model (Table 1 , Model 1A). The predicted probability ${ }^{9}$ of stating that the government should always be responsible for the provision of aid to the unemployed (outcome $=4$ ) is merely $9 \%$ among those who express the strongest opposition to having a non-native marry into their family (with a score of 7 on the prejudice scale), while it is $21 \%$ for those who are least prejudiced (with a score of 1 ; not shown). In other words, the least prejudiced are more than twice as likely to fully

9 Here and throughout the presentation of the results, predictions represent marginal effects at the means of the covariates. 
support government assistance for the unemployed compared to those with the strongest desire for social distance from ethnic out-groups.

Comparing predicted probabilities across the significant associations in Model 1A, the relationship between ethnic prejudice and support for government intervention to assist the jobless appears to be among the strongest. The only predictor associated with a larger change in support probabilities is unemployment itself. However, the difference in 'effect' size is not large: the predicted probability of unemployed respondents to regard the government as fully responsible exceeds that of working ones by a factor of only 2.5 (30 vs. $12 \%)$.

In line with prior research, East Germans' probability of fully supporting government intervention to assist the unemployed is significantly higher, at $19 \%$, than that of their Western compatriots, at $11 \%$. Members of trade unions are also nearly twice as likely to favor the government as mainly responsible for the unemployed (22\%), compared to non-unionized respondents $(12 \%)$. The statistically significant associations observed in Model 1A thus confirm the existence of an East-West divide as well as the importance of self-interest and political alignment as shapers of social policy preferences beyond ethnic prejudice. Yet, these alternative explanations neither rule out the independent relevance of affectively negative out-group sentiment nor does the strength of their associations appear to be much larger in substantive terms.

Contrary to Hypothesis 2, the negative association between prejudice and support for government-provided unemployment assistance does not appear to be moderated by, that is, vary across levels of the subjectively rational assumption that foreign residents impose an economic burden upon the social system. This is reflected in the finding that the interaction between the two types of anti-immigrant sentiment does not achieve statistical significance for support for assistance for the unemployed; the same holds true for support for the old and the sick (cf. Appendix 4).

[Figure 3 about here]

Shedding further light on the relationship between ethnic prejudice and concerns about immigrants' burdening the welfare state, Model 1C in Table 1 shows that the two anti-immigrant sentiment variables are both independently, negatively 
associated with the outcome, though the subjectively rational version achieves significance at the 10-percent level only (also see Model 1B). However, the difference in support probabilities related to changes in the level of ethnic prejudice is larger than that associated with varying levels of agreement with the burden statement (Figure 3, Model 1C). Compared to the most prejudiced respondents, those desiring the least social distance are twice as likely to fully support state intervention assisting the unemployed. By contrast, those who are completely convinced that non-natives do impose economic strain are only 0.7 times less likely to regard the state as primarily responsible for the jobless than those who do not view immigrants as a burden to the welfare state at all. Yet, the difference in support probabilities between respondents harboring the strongest anti-immigrant sentiments on both affective and subjectively rational dimensions is very small (at 10 and $11 \%$, respectively). Nevertheless, the independently significant association of ethnic prejudice renders surprising support to the importance of affect and differential altruism as potential shapers of native support for means-tested welfare in particular, exceeding subjectively rational, economic concerns.

Finally, it remains to be established whether ethnic prejudice (Hypothesis 3) and subjective rationality (Hypothesis 5) are indeed less strongly, if at all, associated with support for assistance for the old and the sick, compared to unemployment aid. To do so, I formally test whether the difference between the coefficients of the two anti-immigrant sentiment variables is equal to zero across models 1-3C (last column in Tables 1, 2, and 3) ${ }^{10}$. The resulting adjusted Wald test statistics (not shown here) are statistically significant, allowing me to reject the hypothesis that the relationship between prejudice and support for the unemployed is equal to that between prejudice and the elderly or the sick. This is the case for the subjective rationality measure as well. While this renders a first instance of support for Hypotheses 3 and 5, visual cross-model comparison further refines the findings:

[Tables 2 and 3 about here]

\footnotetext{
10 This was done using the suest post-estimation tool in Stata (cf. http://www.stata.com/manuals13/rsuest.pdf).
} 
As expected, Tables 2 and 3 show that there is no statistically significant relationship between levels of ethnic prejudice and support for government intervention to assist the sick and the old - the two main recipient groups of Germany's largest universal and contributory welfare programs (Models 2A and 3A). This is so both before and after the controls are introduced to the models (cf. Appendix 3).

Albeit substantively weaker than and statistically significantly different from its negative association with support for the unemployed, the relationship between levels of agreement with the 'immigrants are a burden' statement and support for the state as a care giver for the elderly ( $\mathrm{p}=.056$; Models $2 \mathrm{~B})$ and the sick ( $\mathrm{p}=.052$; Model $3 \mathrm{~B})$ is, surprisingly, positive. However, the positive associations do not turn out to be the largest in substantive terms, especially compared to the education variables. When it comes to old-age assistance, those holding an academic high school degree have two times higher odds of being in a lower support category compared to those with primary education. The predicted probability of being fully supportive of the government's responsibility for the old is equal to $50 \%$ for those with primary and $30 \%$ for those with academic-track, upper secondary education, implying a delta of 20 percentage points. By comparison, the difference in propensities for the highest level of support (Model 2B outcome=maximum value) associated with the lowest (1) and highest (7) levels of agreement with the burden statement amounts to only 10 percentage points.

At face value, the finding that perceiving immigrants as a burden to the social system is significantly negatively associated with support for the government's responsibility to care for the unemployed (Model 1B, supporting Hypothesis 4), but positively associated with support for old-age and sickness assistance (Models 2B and 3B) implies a startling degree of welfare chauvinism: greater concern with the economic viability of non-natives among the claimants of welfare not only implies the contestation of largely means-tested unemployment aid that benefits a substantial number of non-Germans. It is also associated with heightened endorsement of two programs whose recipients are predominantly native. However, as mentioned before, this interpretation should be regarded with care. It is unclear whether natives do in fact base their program support on their concern with immigration-induced strains or whether those who are especially fond of the welfare state are more likely to be 
concerned with immigration as one potential threat to the continued viability of generous social systems. Even so, the fact that the theoretically more intuitive association between ethnic prejudice and preferences for government intervention turns out to be negative for unemployment and nil for old-age and sickness assistance suggests the presence of welfare chauvinism in its own right: independent of subjectively rational concerns, respondents desiring greater social distance from ethnic out-groups are significantly less likely to support aid for the unemployed, among whom individuals with a migration background are over-represented (Model 1C). At the same time, their prejudice has no bearing on support for universal as well as contributory programs that are not connected to notably large non-native recipient groups.

Finally, it should be noted that even the fully controlled models leave a large part of the observed variation in government intervention preferences unexplained, with pseudo $\mathrm{R}^{2}$ values ranging between 3 and $6 \%$. Albeit low in absolute terms, the model fits are very close to those obtained by prior, similarly specified analyses of the link between anti-immigrant sentiment and support for the welfare state in various European contexts (cf. Crepaz 2008; Ford 2006; Senik et al. 2009).

\section{Conclusions}

This study sought to investigate how anti-immigrant sentiment and welfare attitudes are linked among members of the German majority public. Contrary to frequently raised concerns, my analyses do not suggest a link between anti-immigrant sentiment and generalized opposition to state-funded welfare, at least in Germany.

While ethnic prejudice is associated with significantly lowered propensities to support aid for the unemployed (Germany's primary means-tested form of government assistance), it bears no significance for natives' position on aid for the sick and the elderly. Interestingly, the relationships appear to be independent of the extent to which natives believe that foreign residents impose an economic burden upon the welfare system. The magnitude of the negative association between prejudice and support for unemployment assistance also exceeds that between the outcome and the notion of immigrants as a burden. The results thus suggest the importance of negative affect as a potential shaper of native support for means-tested welfare, beyond presumably more rational, economic concerns. 
Against the backdrop of native-born Germans' nearly universal solidarity with the elderly and the sick, the finding that ethnic prejudice matters only when it comes to support for the unemployed implies a pronounced type of welfare chauvinism among people who harbor affectively negative out-group sentiment. With regard to the demography of the groups mainly benefiting from the three kinds of government intervention, the observed support patterns indicate that prejudiced individuals are not only significantly less supportive of aid that benefits a large number of non-natives. They also embrace programs that predominantly target native recipients. In other words, prejudiced individuals do not only structure their program opposition along ethnic (native vs. non-native) lines but their welfare solidarity as well.

Despite these results, it is important to stress that ethnic prejudice does not constitute the sole or strongest predictor of support for government assistance to the jobless. The magnitude of the association is matched, but largely not exceeded, by that of labor force status, union membership, and socialization in East Germany. While this underlines the importance of prejudice, welfare state solidarity among members of the German majority should nevertheless not be described as primarily ethnicized, as was found to be the case in the US. More sophisticated survey instruments should be developed to scrutinize and qualify the findings presented here. Panel data sources will be especially crucial to better understand the relationship between subjectively rational concerns with the economic dimension of immigration and natives' support for various types of welfare.

Moreover, future research should explore the interplay of ethnic prejudice and dimensions of subjectively rational attitudes toward immigrants other than the burden statement used here. For instance, in his afore-mentioned study, Finseraas (2008) finds that natives who fear that immigrants will take their job or lower their income are actually more supportive of redistribution, as they seek compensation for the increasing insecurities caused by the presence of immigrant competitors (Finseraas 2008; also see Burgoon et al. 2012). To limit its scope, the paper at hand focused on studying the interplay of two types on anti-immigrant sentiment in their association with majority support for three types of welfare, to assess whether concerns about the erosion of welfare state endorsement at large are warranted. Whether prejudice might actually be associated with an increased support for certain 
kinds of social insurance in individuals afraid of economic losses due to immigration remains to be studied.

The paper underlines the importance of taking the dimensionality of welfare and redistribution preferences seriously, especially when trying to understand the role of anti-immigrant sentiment. Measures of generalized welfarism often mask substantial variation across types of government assistance, which remains uncaptured in studies utilizing cross-country comparisons to contrast predominantly universal with conservative or liberal, means-testing welfare regime types as well. To further our understanding of the native/non-native divide as a source of differential welfare state support, research would thus not only benefit from the use of more finegrained measures of welfare attitudes but also from in-depth accounts of national discourses and resulting frames of entitlement. 


\section{Acknowledgements}

I would like to especially thank Jens Rydgren, Martin Hällsten, and Stephen Fisher for their support and advice. In addition, this paper benefited greatly from the comments I received at the Berlin Summer School in Social Sciences, the Marie Jahoda Summer School in Vienna, and from Maureen Eger at my halftime seminar at Stockholm University.

The data used in this study are taken from the 2006 German General Social Survey (ALLBUS - Allgemeine Bevölkerungsumfrage der Sozialwissenschaften). The survey was financed by the German federal and state governments. It was organized and implemented by the GESIS research centers in Cologne and Mannheim in cooperation with the ALLBUS committee. The above-mentioned institutions and persons bear no responsibility for the analyses conducted and conclusions drawn in this paper. 


\section{References}

Adema, W., Fron, P. and Ladaique, M. (2012) 'Is the European welfare state really more expensive? Indicators on social spending, 1980-2012 ', OECD Social, Employment and Migration Working Papers 124

Alesina, A. and Glaesner, E. L. (2004) Fighting poverty in the US and Europe: A world of difference. Oxford: Oxford University Press.

Andreß, H. and Heien, T. (2001) 'Four worlds of welfare state attitudes? A comparison of Germany, Norway, and the United States', European Sociological Review 17(4): 337-356.

Appelbaum, L. D. (2002) 'Who deserves help? Students' opinions about the deservingness of different groups living in Germany to receive aid', Social Justice Research 15(3): 201-225.

Bade, K. J. and Oltmer, J. (2004) Migration, Ausländerbeschäftigung und Asylpolitik in der DDR. Bonn: Bundeszentrale für politische Bildung.

BMAS (2014) Sozialbudget 2013. Bonn: Federal Ministry for Work and Social Affairs.

Brewer, M. B. (1979) 'In-group bias in the minimal intergroup situation: A cognitivemotivational analysis', Psychological Bulletin 86(2): 307-324.

Burgoon, B., Koster, F. and van Egmond, M. (2012) 'Support for redistribution and the paradox of immigration', Journal of European Social Policy 22(3): 288-304.

Castronova, E. J., Kayser, H., Frick, J. R. and Wagner, G. G. (2001) 'Immigrants, natives and social assistance: Comparable take-up under comparable circumstances', International Migration Review 35(3): 726-748.

Crepaz, M. M. L. (2008) Trust beyond borders: Immigration, the welfare state, and identity in modern societies. Ann Arbor: University of Michigan Press.

Crepaz, M. M. L. and Damron, R. (2009) 'Constructing tolerance: How the welfare state shapes attitudes about immigrants', Comparative Political Studies 42(3): 437-463.

Decker, O., Kiess, J. and Brähler, E. (2012) Die Mitte im Umbruch: Rechtsextreme Einstellungen in Deutschland 2012. Bonn: Dietz. 
DEStatis. (2009) Bevölkerung und Erwerbstätigkeit: Bevölkerung mit Migrationshintergrund (Ergebnisse des Mikrozensus 2007). Wiesbaden: Federal Statistical Office.

—. (2014) Bevölkerung und Erwerbstätigkeit: Bevölkerung mit Migrationshintergrund (Ergebnisse des Mikrozensus 2013). Wiesbaden: Federal Statistical Office.

Engels, D., Köller, R., Koopmans, R. and Höhne, J. (2011) Zweiter Integrationsindikatorenbericht. Köln/Berlin: ISG/WZB.

Esping-Andersen, G. (1990) The three worlds of welfare capitalism. Princeton, NJ: Princeton University Press.

Eurostat. (2012) Asylum statistics.

Finseraas, H. (2008) 'Immigration and Preferences for Redistribution: An Empirical Analysis of European Survey Data', Comparative European Politics 6 (4): 407431.

Fong, C. M., Bowles, S. and Gintis, H. (2006) 'Strong reciprocity and the welfare state', in S. Kolm and J. Mercier Ythier (eds.), Handbook of the economics of giving, altruism and reciprocity, Burlington: Elsevier, pp. 1439-1464.

Ford, R. (2006) 'Prejudice and white majority welfare attitudes in the UK', Journal of Elections 16 (2): 141-156.

Fox, C. (2004) 'The changing color of welfare? How whites' attitudes toward Latinos influence support for welfare', American Journal of Sociology 110 (3): 580-625.

Friedrich, W. (2001) 'Ist der Rechtsextremismus im Osten ein Produkt der autoritären DDR?', Politik Und Zeitgeschichte 46: 16-23.

Gerhards, J. and Lengfeld, H. (2013) 'European integration, equality rights and People's beliefs: Evidence from Germany', European Sociological Review 29 (1): $19-31$.

Gilens, M. (2000) Why Americans hate welfare: Race, media, and the politics of antipoverty policy. Chicago: University of Chicago Press.

Gorodzeisky, A. (2013) 'Mechanisms of exclusion: Attitudes toward allocation of social rights to out-group population', Ethnic and Racial Studies 36 (5): 795-817.

Gorodzeisky, A. and Semyonov, M. (2009) 'Terms of exclusion: Public views towards admission and allocation of rights to immigrants in European countries', Ethnic and Racial Studies 32 (3): 401-423. 
Hainmueller, J. and Hiscox, M. J. (2010) 'Attitudes toward highly skilled and lowskilled immigration: Evidence from a survey experiment', American Political Science Review, 104 (1), 61-84.

Hamilton, D. L. and Trolier, T. K. (1986) 'Stereotypes and stereotyping: An overview of the cognitive approach', in J. F. Dovidio and S. L. Gaertner (eds.), Prejudice, discrimination, and racism: Theory and research, Orlando, FL: Academic Press, pp. $127-163$

Helbling, M. and Kriesi, H. (2014) 'Why citizens prefer high- over low-skilled immigrants. labor market competition, welfare state, and deservingness', European Sociological Review, 30 (5), 595-614.

Hierl, K. (2012) Die Islamisierung der deutschen Integrationsdebatte: Zur Konstruktion kultureller Identitäten, Differenzen und Grenzziehungen im postkolonialen Diskurs. Berlin: Lit Verlag.

Hox, J. J. (1995) Applied multilevel analysis. Amsterdam: TT-Publikaties.

Khan, S. R. and Lambert, A. J. (2001) 'Perceptions of rational discrimination: When do people attempt to justify race-based prejudice?', Basic and Applied Social Psychology 23 (1), 42-53.

Kohls, M. (2011) Morbidität und Mortalität von Migranten in Deutschland. Nürnberg: Bundesamt für Migration und Flüchtlinge.

Larsen, C. A. (2011) 'Ethnic heterogeneity and public support for welfare: Is the American experience replicated in Britain, Sweden and Denmark?' Scandinavian Political Studies 34(4): 332-353.

Lippl, B. (2001) 'Soziale Sicherheit durch den Sozialstaat? Einschätzungen zu Rente, Arbeitslosigkeit und Krankheit in Ost- und Westdeutschland', Informationsdienst Soziale Indikatoren 26: 7-11.

Mau, S. (2001) 'Patterns of popular support for the welfare state: A comparison of the United Kingdom and Germany’, WZB Discussion Paper.

McLaren, L. M. (2003) 'Anti-immigrant prejudice in Europe: Contact, threat perception, and preferences for the exclusion of migrants', Social Forces 81 (3): 909-936.

OECD. (2014). International migration outlook 2014. Paris: OECD Publishing. 
Peffley, M., Jon Hurwitz and Sniderman, P. M. (1997) 'Racial stereotypes and whites' political views of blacks in the context of welfare and crime', American Journal of Political Science, 41(1), 30-60.

Pettigrew, T. F. (1998) 'Reactions toward the new minorities of Western Europe', Annual Review of Sociology 24 (1): 77-103.

Pratkanis, A. R. (2014 [1989]) 'The cognitive representation of attitudes', in A. R. Pratkanis, S. J. Breckler and A. G. Greenwald (eds.), Attitude structure and function, New York, NY: Psychology Press, pp. 71-98.

Quillian, L. (1995) 'Prejudice as a response to perceived group threat: Population composition and anti-immigrant and racial prejudice in Europe', American Sociological Review 60 (4): 586-611.

Räth, N. and Braakman, A. (2007) Volkswirtschaftliche Gesamtrechnungen: Bruttoinlandsprodukt 2006. Wiesbaden: Federal Statistical Office.

Raijman, R., Semyonov, M. and Schmidt, P. (2003) 'Do foreigners deserve rights? Determinants of public views towards foreigners in Germany and Israel', European Sociological Review 19 (4): 379-392.

Rothstein, B. and Stolle, D. (2003) 'Social capital, impartiality and the welfare state: An institutional approach', in M. Hooghe and D. Stolle (eds.), Generating social capital: Civil society and institutions in comparative perspective, New York, NY: Palgrave Macmillan, pp. 191-209.

Rühl, S. (2009) Grunddaten der Zuwandererbevölkerung in Deutschland.Nürnberg: Federal Office for Migration and Refugees.

Rydgren, J. (2004) 'The logic of xenophobia', Rationality and Society 16(2): 123148.

(2008) 'Immigration skeptics, xenophobes or racists? Radical right-wing voting in six west European countries', European Journal of Political Research 47 (6): 737-765.

Scheepers, P., Gijsberts, M. and Coenders, M. (2002) 'Ethnic exclusionism in European countries. Public opposition to civil rights for legal migrants as a response to perceived ethnic threat', European Sociological Review 18(1): 17-34.

Schmidt-Catran, A.W. and Spies, D. (forthcoming) 'Immigration and Welfare Support in Germany', American Sociological Review. 
Schmidt, A. W. and Spies, D. C. (2014) "Do parties "Playing the race card" undermine natives' support for redistribution? Evidence from Europe', Comparative Political Studies, 47 (4): 519-549.

Semyonov, M., Raijman, R. and Gorodzeisky, A. (2006) 'The rise of anti-foreigner sentiment in European societies, 1988-2000', American Sociological Review 71 (3): 426-449.

Senik, C., Stichnoth, H. and Van der Straeten, K. (2009) 'Immigration and natives' attitudes towards the welfare state: Evidence from the European social survey', Social Indicators Research 91 (3): 345-370.

Stichnoth, H. and Van der Straeten, K. (2013) 'Ethnic diversity, public spending, and individual support for the welfare state: A review of the empirical literature', Journal of Economic Surveys 27 (2): 364-389.

Tajfel, H. (1970) 'Experiments in intergroup discrimination', Scientific American 223: 96-102.

Uske, H. (2000) "'Sozialschmarotzer" und "Versager": Missachtung und Anerkennung in Diskursen über Massenarbeitslosigkeit', in U. Holtgrewe, S. Voswinkel and G. Wagner (eds.), Anerkennung und Arbeit, Konstanz: Univ.Verl., pp. 169-192.

van Oorschot, W. (2006) 'Making the difference in social Europe: Deservingness perceptions among citizens of European welfare states', Journal of European Social Policy 16 (1): 23-42.

Wagner, U., van Dick, R., Pettigrew, T. F. and Christ, O. (2003) 'Ethnic prejudice in East and West Germany: The explanatory power of intergroup contact', Group Processes and Intergroup Relations 6(1): 22-36. 


\section{Figures and Tables}

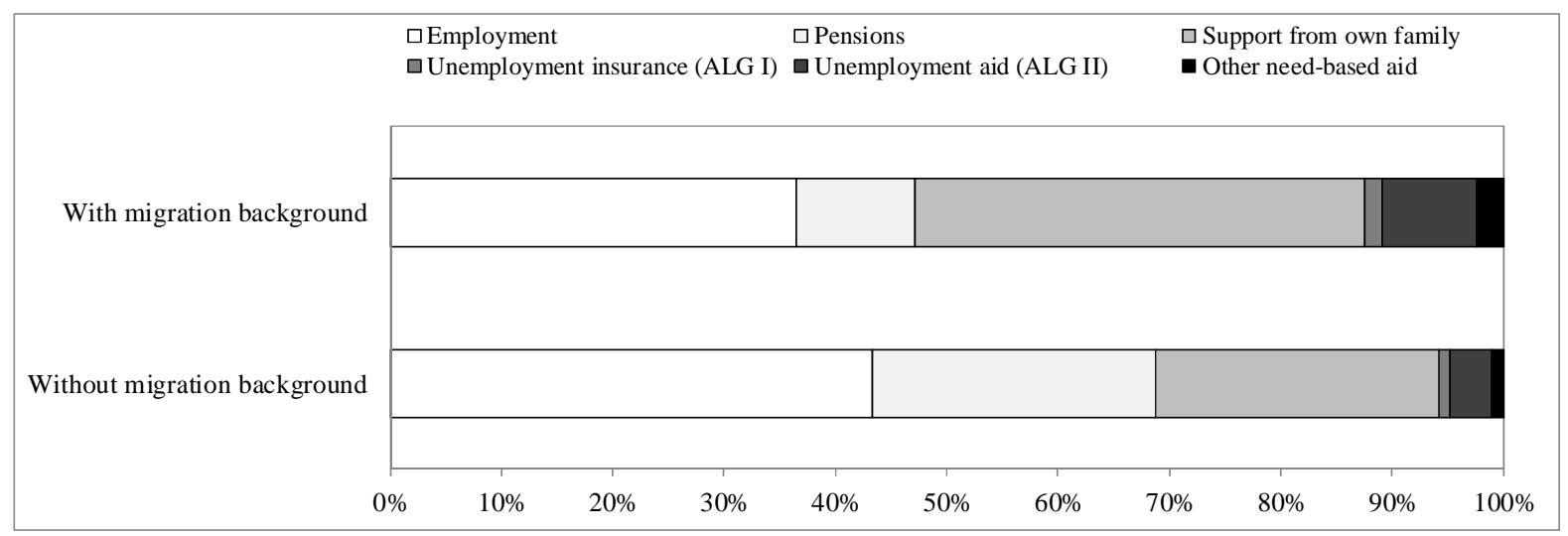

Figure 1. Primary source of income by population group (as a percentage of the sub-population total, 2007)

Note: Own calculations based on the German micro-census of 2007 (DEStatis 2009); 'other need-based aid' includes sustenance grants (Hilfe zum Lebensunterhalt) and interest-free maintenance loans for university students $(B A f \ddot{o} G)$

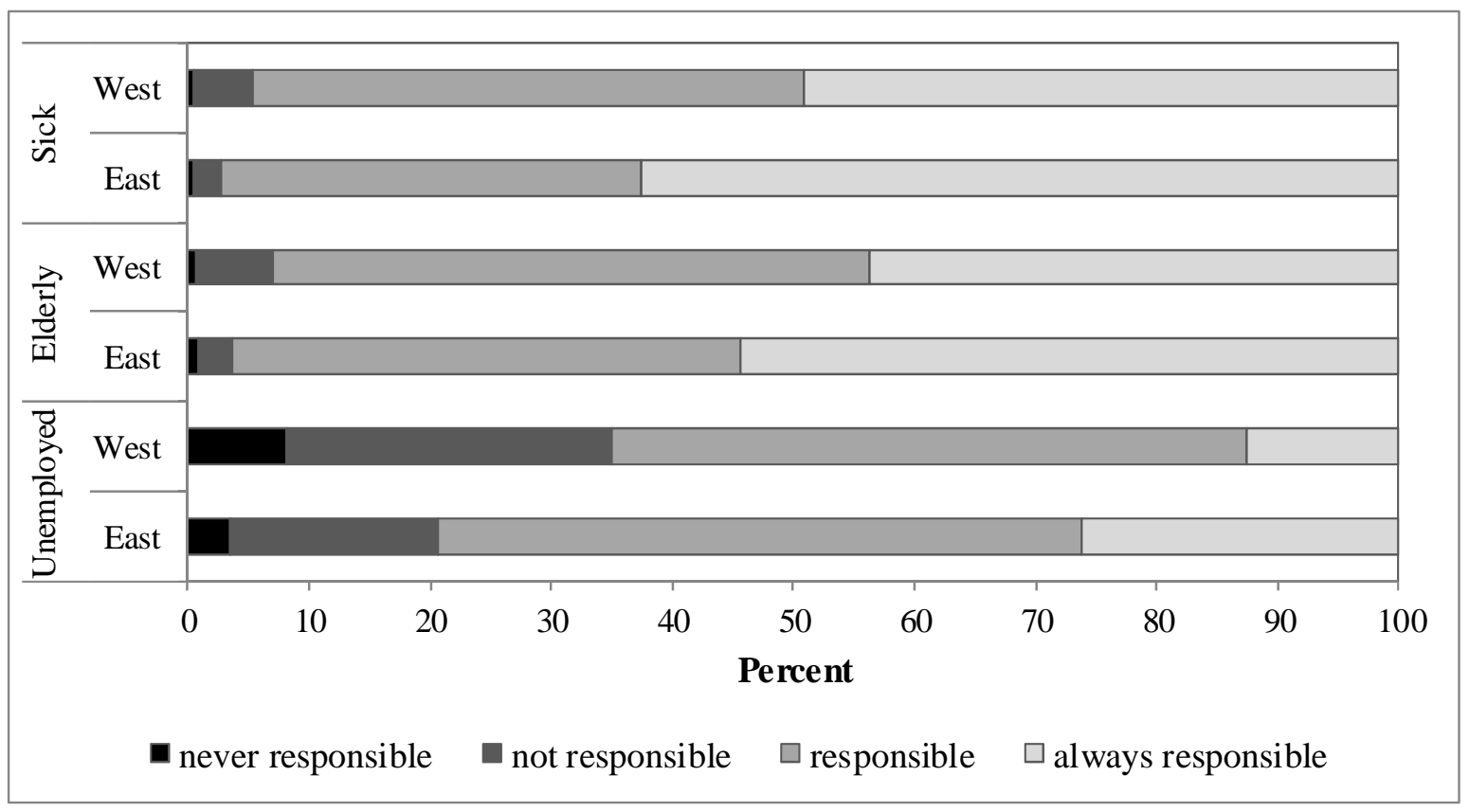

Figure 2. Dependent variables - 'The state should provide a decent standard of living for the sick / the elderly / the unemployed' (answer distributions for East and West Germany)

Note: ALLBUS/ISSP 2006, N= 972; percentages have been weighted to compensate for the oversampling of East German respondents 


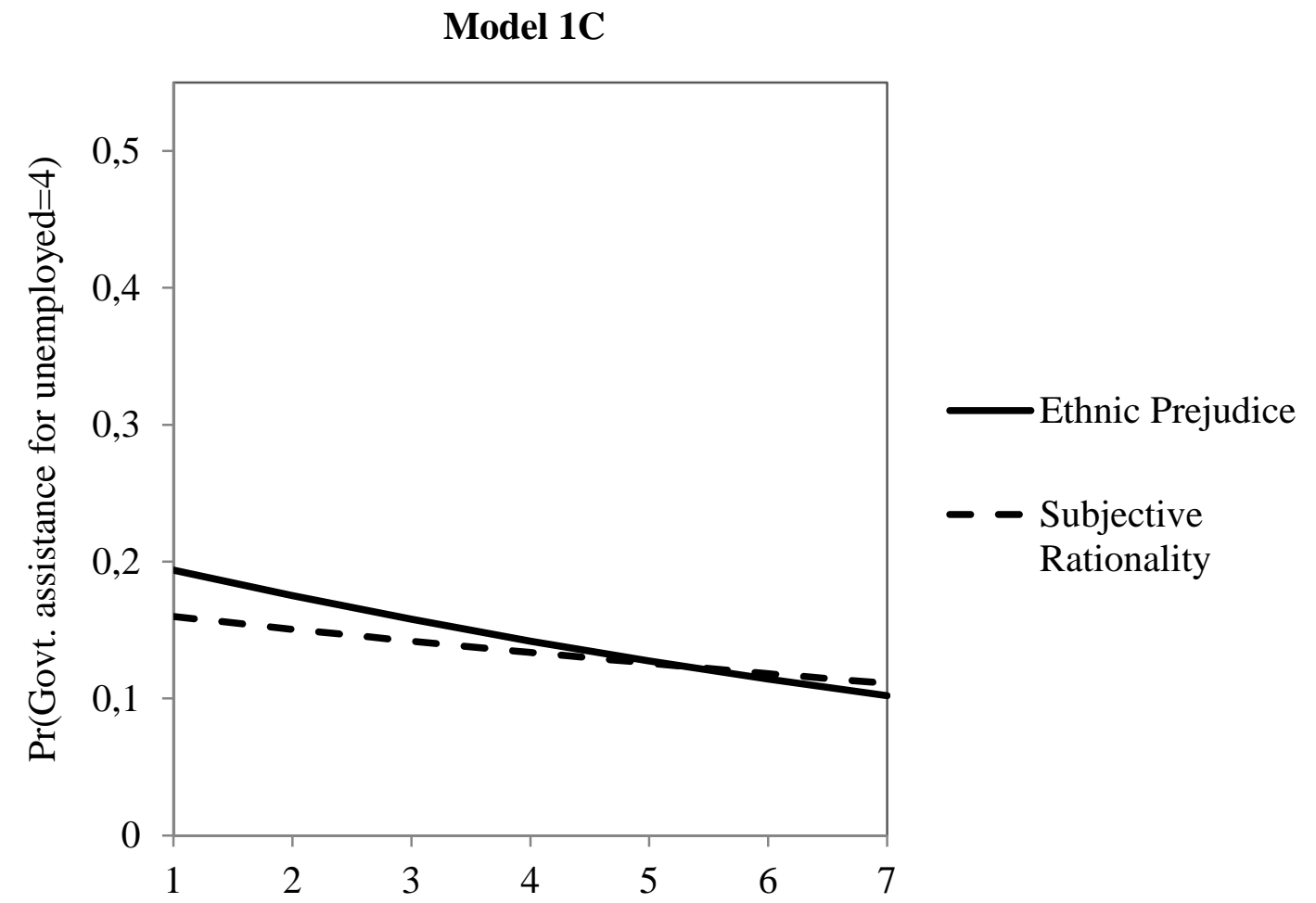

Figure 3. Predicted probabilities - full support for government intervention to assist the unemployed Note: Predictions based on Model 1C (Table 1) with all covariates at their mean values 
Table 1. Support for the government's responsibility to care for the unemployed (ordered logit)

\begin{tabular}{|c|c|c|c|}
\hline & $(1 \mathrm{~A})$ & (1B) & $(1 \mathrm{C})$ \\
\hline Ethnic prejudice & $-0.15^{* *}(0.058)$ & - & $-0.125^{*}(0.058)$ \\
\hline Subjective rationality & - & $-0.098^{*}(0.04)$ & $-0.07^{+}(0.04)$ \\
\hline Age & $0.017^{*}(0.007)$ & $0.015^{*}(0.007)$ & $0.017^{*}(0.007)$ \\
\hline Female & $-0.137(0.135)$ & $-0.094(0.131)$ & $-0.127(0.133)$ \\
\hline Youth in East Germany & $0.602^{* *}(0.197)$ & $0.621^{* *}(0.202)$ & $0.641^{* *}(0.202)$ \\
\hline Household income (month) & $-0.056^{* *}(0.02)$ & $-0.061^{* *}(0.02)$ & $-0.058^{* *}(0.021)$ \\
\hline \multicolumn{4}{|l|}{ Labor force status } \\
\hline Pensioner & $0.265(0.211)$ & $0.282(0.208)$ & $0.276(0.209)$ \\
\hline Not working, other reason & $0.370(0.266)$ & $0.351(0.265)$ & $0.352(0.263)$ \\
\hline Not working, unemployed & $1.147^{* * * *}(0.273)$ & $1.094^{* * *}(0.269)$ & $1.103^{* * *}(0.273)$ \\
\hline Self-employed & $-0.672^{+}(0.397)$ & $-0.603(0.390)$ & $-0.660^{+}(0.397)$ \\
\hline Public-sector employment & $0.341^{+}(0.191)$ & $0.324^{+}(0.189)$ & $0.325^{+}(0.19)$ \\
\hline \multicolumn{4}{|l|}{ Marital status } \\
\hline Separated/divorced & $0.262(0.250)$ & $0.220(0.249)$ & $0.248(0.251)$ \\
\hline Widowed & $-0.247(0.337)$ & $-0.215(0.341)$ & $-0.235(0.336)$ \\
\hline Single & $-0.300(0.208)$ & $-0.309(0.208)$ & $-0.308(0.208)$ \\
\hline \multicolumn{4}{|l|}{ Education } \\
\hline Middle school & $0.032(0.175)$ & $0.0223(0.170)$ & $0.015(0.172)$ \\
\hline High school - vocational & $0.187(0.229)$ & $0.125(0.227)$ & $0.14(0.228)$ \\
\hline High school-academic & $0.175(0.217)$ & $0.180(0.213)$ & $0.134(0.217)$ \\
\hline Political ideology (left - right) & $-0.072^{+}(0.043)$ & $-0.081^{+}(0.044)$ & $-0.066(0.043)$ \\
\hline Union member & $0.694^{* *}(0.247)$ & $0.689^{* *}(0.246)$ & $0.69^{* *}(0.245)$ \\
\hline Pseudo $R^{2}$ & 0.0637 & 0.0622 & 0.0653 \\
\hline Observations & 972 & 972 & 972 \\
\hline
\end{tabular}

${ }^{+} p \leq 0.10,{ }^{*} p \leq 0.05,{ }^{* *} p \leq 0.01,{ }^{* * *} p \leq 0.001$

Note: Table presents untransformed regression coefficients, with standard errors in parentheses (adjusted for data clustering in 158 primary sampling units/municipalities; sample weighted to adjust for oversampling in East Germany); omitted reference categories = working, mandatory nine-year education, married 
Table 2. Support for the government's responsibility to care for the elderly (ordered logit)

\begin{tabular}{|c|c|c|c|}
\hline & $(2 \mathrm{~A})$ & $(2 \mathrm{~B})$ & $(2 \mathrm{C})$ \\
\hline Ethnic prejudice & $0.017(0.053)$ & - & $-0.01(0.053)$ \\
\hline Subjective rationality & - & $0.07^{+}(0.037)$ & $0.073^{*}(0.037)$ \\
\hline Age & $-0.002(0.008)$ & $-0.002(0.008)$ & $-0.002(0.008)$ \\
\hline Female & $-0.098(0.160)$ & $-0.107(0.16)$ & $-0.109(0.16)$ \\
\hline Youth in East Germany & $0.303^{+}(0.186)$ & $0.259(0.19)$ & $0.261(0.19)$ \\
\hline Household income (month) & $-0.03(0.02)$ & $-0.029(0.02)$ & $-0.029(0.02)$ \\
\hline \multicolumn{4}{|l|}{ Labor force status } \\
\hline Pensioner & $0.089(0.256)$ & $0.087(0.253)$ & $0.088(0.254)$ \\
\hline Not working, other reason & $0.184(0.274)$ & $0.207(0.272)$ & $0.207(0.272)$ \\
\hline Not working, unemployed & $0.003(0.269)$ & $0.05(0.269)$ & $0.051(0.269)$ \\
\hline Self-employed & $-0.279(0.306)$ & $-0.292(0.308)$ & $-0.295(0.308)$ \\
\hline Public-sector employment & $-0.201(0.232)$ & $-0.181(0.235)$ & $-0.181(0.235)$ \\
\hline \multicolumn{4}{|l|}{ Marital Status } \\
\hline Separated/divorced & $0.356(0.260)$ & $0.371(0.263)$ & $0.373(0.262)$ \\
\hline Widowed & $0.200(0.324)$ & $0.192(0.320)$ & $0.192(0.320)$ \\
\hline Single & $-0.375^{+}(0.229)$ & $-0.366(0.232)$ & $-0.367(0.232)$ \\
\hline \multicolumn{4}{|l|}{ Education } \\
\hline Middle school & $-0.409^{*}(0.179)$ & $-0.389^{*}(0.177)$ & $-0.389^{*}(0.178)$ \\
\hline High school - vocational & $-0.330(0.228)$ & $-0.283(0.228)$ & $-0.282(0.227)$ \\
\hline High school-academic & $-0.734^{* * * *}(0.195)$ & $-0.688^{* * *}(0.195)$ & $-0.692^{* * *}(0.197)$ \\
\hline Political ideology (left - right) & $-0.08^{+}(0.043)$ & $-0.087^{*}(0.042)$ & $-0.085^{*}(0.043)$ \\
\hline Union member & $0.148(0.225)$ & $0.161(0.227)$ & $0.161(0.228)$ \\
\hline Pseudo $R^{2}$ & 0.0333 & 0.0354 & 0.0355 \\
\hline Observations & 972 & 972 & 972 \\
\hline
\end{tabular}

${ }^{+} p \leq 0.10,{ }^{*} p \leq 0.05,{ }^{* *} p \leq 0.01,{ }^{* * * *} p \leq 0.001$

Note: Table presents untransformed regression coefficients, with standard errors in parentheses (adjusted for data clustering in 158 primary sampling units/municipalities; sample weighted to adjust for oversampling in East Germany); omitted reference categories = working, mandatory nine-year education, married 
Table 3. Support for the government's responsibility to care for the sick (ordered logit)

\begin{tabular}{|c|c|c|c|}
\hline & $(3 \mathrm{~A})$ & (3B) & (3C) \\
\hline Ethnic prejudice & $0.049(0.053)$ & - & $0.021(0.053)$ \\
\hline Subjective rationality & - & $0.081^{+}(0.042)$ & $0.076^{+}(0.042)$ \\
\hline Age & $-0.011(0.008)$ & $-0.01(0.008)$ & $-0.011(0.008)$ \\
\hline Female & $0.192(0.152)$ & $0.177(0.155)$ & $0.181(0.153)$ \\
\hline Youth in East Germany & $0.401^{*}(0.194)$ & $0.361^{+}(0.198)$ & $0.358^{+}(0.199)$ \\
\hline Household income (month) & $-0.038^{+}(0.021)$ & $-0.037^{+}(0.021)$ & $-0.037^{+}(0.02)$ \\
\hline \multicolumn{4}{|l|}{ Labor force status } \\
\hline Pensioner & $0.377(0.281)$ & $0.368(0.28)$ & $0.367(0.280)$ \\
\hline Not working, other reason & $0.275(0.271)$ & $0.297(0.266)$ & $0.297(0.267)$ \\
\hline Not working, unemployed & $0.221(0.269)$ & $0.267(0.266)$ & $0.266(0.267)$ \\
\hline Self-employed & $-0.125(0.303)$ & $-0.145(0.307)$ & $-0.14(0.306)$ \\
\hline Public-sector employment & $-0.064(0.248)$ & $-0.039(0.25)$ & $-0.04(0.25)$ \\
\hline \multicolumn{4}{|l|}{ Marital status } \\
\hline Separated/divorced & $0.067(0.230)$ & $0.086(0.23)$ & $0.083(0.228)$ \\
\hline Widowed & $-0.002(0.320)$ & $-0.015(0.314)$ & $-0.013(0.315)$ \\
\hline Single & $-0.466^{*}(0.210)$ & $-0.458^{*}(0.210)$ & $-0.458^{*}(0.21)$ \\
\hline \multicolumn{4}{|l|}{ Education } \\
\hline Middle school & $-0.263(0.188)$ & $-0.248(0.185)$ & $-0.248(0.186)$ \\
\hline High school - vocational & $-0.253(0.336)$ & $-0.206(0.331)$ & $-0.21(0.332)$ \\
\hline High school - academic & $-0.587^{* *}(0.208)$ & $-0.554^{* *}(0.208)$ & $-0.546^{* *}(0.21)$ \\
\hline Political ideology (left - right) & $-0.086^{*}(0.043)$ & $-0.09^{*}(0.043)$ & $-0.093^{*}(0.044)$ \\
\hline Union member & $0.163(0.227)$ & $0.178(0.23)$ & $0.178(0.23)$ \\
\hline Bad health & $0.210(0.199)$ & $0.19(0.20)$ & $0.194(0.201)$ \\
\hline Pseudo $R^{2}$ & 0.0382 & 0.0405 & 0.0406 \\
\hline Observations & 972 & 972 & 972 \\
\hline
\end{tabular}

${ }^{+} p \leq 0.10,{ }^{*} p \leq 0.05,{ }^{* *} p \leq 0.01$

Note: Table presents untransformed regression coefficients, with standard errors in parentheses (adjusted for data clustering in 158 primary sampling units/municipalities; sample weighted to adjust for oversampling in East Germany); omitted reference categories = working, mandatory nine-year education, married 
Appendix 1. Independent variables

\begin{tabular}{|c|c|c|c|c|c|}
\hline Variable & Coding & Mean & SD & Min & $\operatorname{Max}$ \\
\hline Ethnic prejudice & $\begin{array}{l}\text { Continuous, three-item additive scale: } \\
\text { 'In how far would it be pleasant or unpleasant } \\
\text { for you if ... } \\
\quad \text { - a Turkish person } \\
\quad \text { - an Aussiedler } \\
\quad \text { - an asylum seeker } \\
\quad \text {... married into your family? } \\
\begin{array}{l}1 \text { = very pleasant, ... } \\
7 \text { = very unpleasant }\end{array}\end{array}$ & 4.66 & 1.50 & 1 & 7 \\
\hline Subjective rationality & $\begin{array}{l}\text { Continuous, single-item indicator: } \\
\text { 'The foreigners who live in Germany are a } \\
\text { burden on the social welfare system.' } \\
1=\text { completely disagree, ... } \\
7=\text { completely agree }\end{array}$ & 4.19 & 1.87 & 1 & 7 \\
\hline Age & Continuous (years; mean-centered) & 50.13 & 16.99 & 18 & 91 \\
\hline Gender & Indicator $(1=$ female $)$ & 0.51 & . & 0 & 1 \\
\hline $\begin{array}{l}\text { Socialization in } \\
\text { East Germany }\end{array}$ & $\begin{array}{l}\text { Indicator }(1=\text { spent most of childhood and } \\
\text { youth in East Germany or former GDR) }\end{array}$ & 0.26 & . & 0 & 1 \\
\hline Household income & 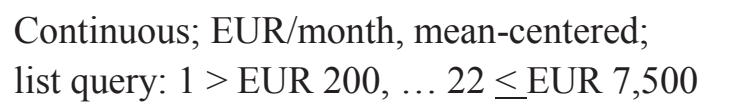 & 14.18 & 4.57 & 0 & 22 \\
\hline Labor force status & $\begin{array}{l}\text { Indicator (four levels) } \\
\text { working (ref.) } \\
\text { not working, unemployed } \\
\text { not working, other reason } \\
\text { pensioner } \\
\text { Indicator (single items) } \\
\text { self-employed } \\
\text { public-sector employment }\end{array}$ & $\begin{array}{l}0.49 \\
0.10 \\
0.12 \\
0.29\end{array}$ & $\begin{array}{l}. \\
. \\
.\end{array}$ & $\begin{array}{l}0 \\
0 \\
0 \\
0\end{array}$ & $\begin{array}{l}1 \\
1 \\
1 \\
1\end{array}$ \\
\hline Marital status & $\begin{array}{l}\text { Indicators (four levels) } \\
\text { married (ref.) } \\
\text { separated/divorced } \\
\text { widowed } \\
\text { single }\end{array}$ & $\begin{array}{l}0.60 \\
0.11 \\
0.07 \\
0.22\end{array}$ & $\begin{array}{l}. \\
. \\
.\end{array}$ & $\begin{array}{l}0 \\
0 \\
0 \\
0\end{array}$ & $\begin{array}{l}1 \\
1 \\
1 \\
1\end{array}$ \\
\hline Education & $\begin{array}{l}\text { Indicator (four levels) } \\
\text { mandatory nine-year education (ref.) } \\
\text { middle school } \\
\text { secondary school - vocational } \\
\text { secondary school - academic }\end{array}$ & $\begin{array}{l}0.39 \\
0.32 \\
0.08 \\
0.21\end{array}$ & $\begin{array}{l}. \\
. \\
.\end{array}$ & $\begin{array}{l}0 \\
0 \\
0 \\
0\end{array}$ & $\begin{array}{l}1 \\
1 \\
1 \\
1\end{array}$ \\
\hline Political ideology & $\begin{array}{l}\text { Continuous; self-placement on left-right scale } \\
\text { where } 1=\text { left, } \ldots 10=\text { right }\end{array}$ & 5.28 & 1.81 & 1 & 10 \\
\hline Union membership & Indicator $(1=$ union member $)$ & 0.12 & . & 0 & 1 \\
\hline Health & Indicator ( $1=$ bad health; self-rated $)$ & 0.14 & . & 0 & 1 \\
\hline
\end{tabular}


Appendix 2. Independent variables - correlation matrix

\begin{tabular}{|c|c|c|c|c|c|c|c|c|c|c|c|c|c|c|c|c|c|c|c|c|}
\hline & Age & Female & $\begin{array}{c}\mathrm{HH} \\
\text { inco. }\end{array}$ & Pension & $\begin{array}{c}\text { No } \\
\text { work }\end{array}$ & Unemp. & $\begin{array}{l}\text { Self- } \\
\text { emp. }\end{array}$ & Public & $\begin{array}{c}\text { High - } \\
\text { voc. }\end{array}$ & $\begin{array}{l}\text { Middle } \\
\text { school }\end{array}$ & $\begin{array}{l}\text { High - } \\
\text { acad. }\end{array}$ & Separ. & Widow & Single & $\begin{array}{l}\text { East } \\
\text { Ger. }\end{array}$ & $\begin{array}{l}\text { Left- } \\
\text { right }\end{array}$ & Union & $\begin{array}{c}\text { Bad } \\
\text { health }\end{array}$ & $\begin{array}{l}\text { Ethnic } \\
\text { preju. }\end{array}$ & $\begin{array}{l}\text { Subj. } \\
\text { rat. }\end{array}$ \\
\hline Age & 1 & & & & & & & & & & & & & & & & & & & \\
\hline Female & $0.071^{*}$ & 1 & & & & & & & & & & & & & & & & & & \\
\hline HH income & $-0.069^{*}$ & $-0.056^{+}$ & 1 & & & & & & & & & & & & & & & & & \\
\hline Pensioner & $0.733^{* * * *}$ & 0.03 & $-0.17^{* * *}$ & 1 & & & & & & & & & & & & & & & & \\
\hline No work & $-0.17^{* * *}$ & $0.254^{* * *}$ & $-0.058^{+}$ & $-0.23^{* * *}$ & 1 & & & & & & & & & & & & & & & \\
\hline Unempl. & $-0.16^{* * *}$ & $-0.067^{*}$ & $-0.27^{* * *}$ & $-0.21^{* * * *}$ & $-0.12^{* * * *}$ & 1 & & & & & & & & & & & & & & \\
\hline Self-empl. & -0.031 & $-0.09^{* *}$ & $0.120^{* * * *}$ & $-0.17^{* * *}$ & $-0.098^{* * *}$ & $-0.088^{* *}$ & 1 & & & & & & & & & & & & & \\
\hline Public & $-0.15^{* * *}$ & 0.035 & $0.199^{* * *}$ & $-0.23^{* * *}$ & $-0.13^{* * *}$ & $-0.12^{* * * *}$ & $-0.097^{* *}$ & 1 & & & & & & & & & & & & \\
\hline $\begin{array}{l}\text { High } \\
\text { - vocation }\end{array}$ & $-0.059^{+}$ & $-0.073^{*}$ & $0.119^{* * *}$ & -0.052 & -0.043 & $-0.068^{*}$ & 0.0001 & $0.12^{* * *}$ & 1 & & & & & & & & & & & \\
\hline Middle & $-0.13^{* * *}$ & $0.095^{* *}$ & -0.001 & $-0.15^{* * *}$ & -0.007 & $0.071^{*}$ & -0.031 & -0.029 & $-0.19^{* * *}$ & 1 & & & & & & & & & & \\
\hline $\begin{array}{l}\text { High } \\
\text { - academic }\end{array}$ & $-0.22^{* * *}$ & -0.042 & $0.233^{* * *}$ & $-0.16^{* * *}$ & $0.09^{* *}$ & -0.044 & $0.063^{*}$ & $0.169^{* * *}$ & $-0.15^{* * *}$ & $-0.36^{* * *}$ & 1 & & & & & & & & & \\
\hline $\begin{array}{l}\text { Separated/ } \\
\text { divorced }\end{array}$ & -0.0019 & $0.066^{*}$ & $-0.22^{* * *}$ & $-0.07^{*}$ & $-0.061^{+}$ & $0.073^{*}$ & 0.029 & 0.037 & -0.035 & $0.076^{*}$ & 0.017 & 1 & & & & & & & & \\
\hline Widowed & $0.335^{* * *}$ & $0.178^{* * * *}$ & $-0.21^{* * *}$ & $0.311^{* * *}$ & -0.049 & $-0.063^{*}$ & -0.052 & $-0.08^{*}$ & $-0.076^{*}$ & -0.049 & $-0.096^{* *}$ & $-0.093^{* *}$ & 1 & & & & & & & \\
\hline Single & $-0.55^{* * * *}$ & $-0.17^{* * * *}$ & $-0.21^{* * *}$ & $-0.28^{* * *}$ & $0.081^{*}$ & $0.151^{* * * *}$ & $-0.061^{+}$ & -0.023 & 0.004 & -0.01 & $0.178^{* * * *}$ & $-0.19^{* * *}$ & $-0.15^{* * *}$ & 1 & & & & & & \\
\hline East Ger. & -0.016 & 0.026 & $-0.21^{* * *}$ & 0.044 & $-0.097^{* *}$ & $0.127^{* * *}$ & $-0.085^{* *}$ & -0.033 & $-0.079^{*}$ & $0.197^{* * *}$ & $-0.087^{* *}$ & 0.022 & -0.004 & $0.057^{+}$ & 1 & & & & & \\
\hline Left-right & $0.091^{* *}$ & $-0.062^{+}$ & -0.034 & $0.082^{*}$ & -0.005 & -0.006 & -0.006 & $-0.091^{* *}$ & -0.045 & -0.029 & $-0.074^{*}$ & -0.022 & $0.112^{* * *}$ & -0.009 & $-0.17^{* * * *}$ & 1 & & & & \\
\hline Union & 0.002 & $-0.20^{* * * *}$ & $0.085^{* *}$ & -0.037 & $-0.10^{* * *}$ & 0.0274 & -0.039 & $0.07^{*}$ & -0.003 & 0.028 & -0.011 & -0.049 & $-0.069^{*}$ & -0.036 & -0.028 & $-0.081^{*}$ & 1 & & & \\
\hline Bad health & $0.193^{* * * *}$ & 0.018 & $-0.16^{* * * *}$ & $0.170^{* * * *}$ & -0.023 & $0.066^{*}$ & -0.042 & $-0.057^{+}$ & $-0.079^{*}$ & $-0.063^{*}$ & $-0.097^{* *}$ & 0.038 & 0.047 & $-0.11^{* * *}$ & 0.048 & -0.029 & -0.017 & 1 & & \\
\hline Ethnic prej. & $0.151^{* * * *}$ & $-0.071^{*}$ & -0.017 & $0.136^{* * *}$ & $-0.075^{*}$ & -0.037 & -0.051 & -0.049 & 0.014 & 0.019 & $-0.17^{* * * *}$ & 0.0058 & $0.053^{+}$ & $-0.081^{*}$ & $0.054^{+}$ & $0.197^{* * * *}$ & -0.015 & 0.002 & 1 & \\
\hline $\begin{array}{l}\text { Subjective } \\
\text { rationality }\end{array}$ & $0.111^{* * *}$ & 0.028 & $-0.087^{* *}$ & $0.137^{* * * *}$ & -0.053 & $-0.071^{*}$ & -0.008 & $-0.099^{* *}$ & $-0.073^{*}$ & 0.029 & $-0.18^{* * *}$ & -0.035 & $0.096^{* *}$ & -0.052 & $0.149^{* * * *}$ & $0.130^{* * * *}$ & $-0.058^{+}$ & $0.066^{*}$ & $0.343^{* * * *}$ & 1 \\
\hline
\end{tabular}


Appendix 3. Bivariate associations

\begin{tabular}{lcccccc}
\hline & \multicolumn{2}{c}{ Unemployed } & \multicolumn{2}{c}{ Old } & \multicolumn{2}{c}{ Sick } \\
\cline { 2 - 7 } & $(1 \mathrm{~A})$ & $(1 \mathrm{~B})$ & $(2 \mathrm{~A})$ & $(2 \mathrm{~B})$ & $(3 \mathrm{~A})$ & $(3 \mathrm{~B})$ \\
\hline Ethnic prejudice & $-0.111^{*}$ & - & 0.0483 & - & 0.0578 & - \\
& $(0.054)$ & & $(0.049)$ & & $(0.049)$ & \\
Subjective rationality & - & $-0.0741^{+}$ & - & $0.102^{* *}$ & - & $0.109^{* *}$ \\
& & $(0.038)$ & & $(0.035)$ & & $(0.038)$ \\
Pseudo $R^{2}$ & 0.0031 & 0.0023 & 0.0008 & 0.0052 & 0.0011 & 0.0062 \\
\hline
\end{tabular}

${ }^{+} p \leq 0.10,{ }^{*} p \leq 0.05,{ }^{* *} p \leq 0.01,{ }^{* * *} p \leq 0.001$

Note: $\mathrm{N}=972$ 
Appendix 4. Support for government intervention and ethnic prejudice across levels of agreement that 'foreigners who live in Germany are a burden to the social system' (subjective rationality; ordered logit)

The government is responsible to care for ...

the unemployed the old sick

(1)

(2)

(3)

\begin{tabular}{|c|c|c|c|}
\hline Ethnic prejudice & $0.034(0.118)$ & $-0.146(0.09)$ & $-0.063(0.107)$ \\
\hline Subjective rationality & $0.110(0.122)$ & $-0.08(0.108)$ & $-0.02(0.117)$ \\
\hline \multicolumn{4}{|l|}{ Interaction } \\
\hline Prejudice*Rationality & $-0.038(0.025)$ & $0.033(0.022)$ & $0.02(0.024)$ \\
\hline Age & $0.016^{*}(0.007)$ & $-0.002(0.008)$ & $-0.011(0.008)$ \\
\hline Female & $-0.122(0.135)$ & $-0.115(0.162)$ & $0.177(0.154)$ \\
\hline Youth in East Germany & $0.631^{* *}(0.199)$ & $0.274(0.19)$ & $0.366^{+}(0.199)$ \\
\hline Household income (month) & $-0.059^{* *}(0.021)$ & $-0.028(0.02)$ & $-0.037^{+}(0.02)$ \\
\hline \multicolumn{4}{|l|}{ Labor force status } \\
\hline Pensioner & $0.271(0.209)$ & $0.098(0.254)$ & $0.372(0.279)$ \\
\hline Not working, other reason & $0.327(0.267)$ & $0.225(0.27)$ & $0.309(0.266)$ \\
\hline Not working, unemployed & $1.109^{* * *}(0.275)$ & $0.044(0.267)$ & $0.263(0.265)$ \\
\hline Self-employed & $-0.674^{+}(0.397)$ & $-0.290(0.308)$ & $-0.134(0.305)$ \\
\hline Public-sector employment & $0.319^{+}(0.187)$ & $-0.178(0.237)$ & $-0.037(0.251)$ \\
\hline \multicolumn{4}{|l|}{ Marital status } \\
\hline Separated/divorced & $0.261(0.249)$ & $0.360(0.262)$ & $0.0742(0.226)$ \\
\hline Widowed & $-0.262(0.333)$ & $0.204(0.32)$ & $-0.002(0.314)$ \\
\hline Single & $-0.304(0.207)$ & $-0.383(0.234)$ & $-0.468^{*}(0.212)$ \\
\hline \multicolumn{4}{|l|}{ Education } \\
\hline High school-vocational & $0.132(0.228)$ & $-0.278(0.226)$ & $-0.208(0.331)$ \\
\hline Middle school & $-0.001(0.172)$ & $-0.379^{*}(0.176)$ & $-0.241(0.185)$ \\
\hline High school-academic & $0.140(0.215)$ & $-0.702^{* * * *}(0.196)$ & $-0.551^{* *}(0.208)$ \\
\hline Political ideology (left-right) & $-0.0647(0.044)$ & $-0.087^{*}(0.043)$ & $-0.094^{*}(0.044)$ \\
\hline Union member & $0.688^{* *}(0.246)$ & $0.154(0.227)$ & $0.173(0.228)$ \\
\hline Bad health & - & - & $0.194(0.201)$ \\
\hline Pseudo $R^{2}$ & 0.0666 & 0.0367 & 0.0411 \\
\hline Observations & 972 & 972 & 972 \\
\hline
\end{tabular}

${ }^{+} p \leq 0.10,{ }^{*} p \leq 0.05,{ }^{* *} p \leq 0.01,{ }^{* * *} p \leq 0.001$ 